\title{
TEACHER'S REFLECTION OF INQUIRY TEACHING IN FINLAND BEFORE AND DURING AN IN-SERVICE PROGRAM: EXAMINATION BY A PROGRESS MODEL OF COLLABORATIVE REFLECTION
}

Received: 21 July 2011; Accepted: 16 March 2012

\begin{abstract}
In inquiry-based science education, there have been gradual shifts in research interests: the nature of scientific method, the debates on the effects of inquiry learning, and, recently, inquiry teaching. However, many in-service programs for inquiry teaching have reported inconsistent results due to the static view of classroom inquiries and due to the partial perspective between individual and collaborative reflections. Thus, by means of a theoretical progress model of collaborative reflection, this qualitative research aims to investigate reflections of four participant teachers before and during a half-year in-service teacher program. The model captures the following four interactions for each individual teacher and among the teacher cohort: belief to practice, practice to belief, stimulation, and reinforcement. The audio-video data and their quantification allowed identification of the teachers' consistent prior beliefs and practices as a multiplicity of inquiry teaching and their interwoven progress during the program. The findings are further discussed in terms of the implicit development and the richer repertoire.
\end{abstract}

KEY WORDS: collaborative reflection, inquiry teaching, teacher belief, teacher practice

\section{INTRODUCTION}

Although there were debates about the "myth of the scientific method" and philosophers argued about the nature of the scientific method (Kuhn, 1996), many countries have emphasized teaching and learning science through inquiry activities (Bybee, 1997; NRC, 1996). This trend originated from a focus on attainment: Inquiry learning positively influences students' learning outcomes through their reasoning ability (Johnson \& Lawson, 1998), scientific literacy (Bybee, 1997), or sustainable motivation in learning science (Wellington, 1989). In spite of its growing necessity, however, inquiry teaching has not been implemented as much as it was appreciated due to teachers' traditional beliefs and practices. For example, the use of inquiry teaching in Finland

Electronic supplementary material The online version of this article (doi:10.1007/s10763-0129341-4) contains supplementary material, which is available to authorized users. 
was determined to be lower than the OECD average (OECD, 2007); inquiry teaching is shown to negatively predict or discourage Finnish student's scientific literacy (Lavonen \& Laaksonen, 2009). Tytler, Osborne, Williams, Tytler \& Cripps Clark (2008) claimed, "A shift to inquiry teaching requires a significant shift in teacher beliefs and the development of new skills" (p. 66).

In-service programs designed for disseminating inquiry teaching have been evaluated as producing inconsistent results with regard to teacher's sustainable professional development (Nelson, 2009). In these teachertraining programs, the methodology to monitor the progress focused on a repeated-measure experiment in which an identical cohort of teachers was measured prior and consequent to the treatment through testing whether there was a significant change in the participant teachers. In the light of this, Oliveira (2010) recently states that many short-term professional development programs provide limited information and fail to foster teachers' deeper understanding of classroom inquiries as much as they were intended. Oliveira's emphasis on the relevant and dynamic view of classroom inquiries highlights the need to answer questions such as "What belief and practice does each participant teacher hold prior to an in-service teacher program?" and "Has the contextual development been properly examined during the program?"

Reflections on teachers' beliefs and practices have long been regarded to facilitate professional development, so much so that teacher educators have endeavored to promote them in their individual and collaborative perspectives. In the studies about the individual perspective of teacher's reflection, many have described interactions between a teacher's beliefs and practices (Bianchini \& Colburn, 2000; Mansvelder-Longayroux, Beijaard \& Verloop, 2007). The literature suggests that identifying a teacher profile could be an effective tool to enact reflections and to increase their perceived relevance of an in-service program. In a collaborative perspective of teacher's reflection, the reflection facilitates teachers' knowledge to be commonly shared and supports teachers' learning from their experiences (Hiebert, Gallimore \& Stigler, 2002). Sowder (2007) stated that knowledge for practice demonstrated by other teachers is a common form of acquiring new instructional practices such as inquiry teaching. Such professional development has been found to effectively occur when teachers work in a small group reflecting on their own or colleagues' instructional beliefs and practices (Falk \& Drayton, 2009; Linn, 2009; Yoon \& Kim, 2010).

A progress model that examines these interwoven reflections may provide a more valid description of how participant teachers change their 
beliefs and practices of inquiry teaching, as Oliveira (2010) points to "social understandings of oral strategies that they can adopt while facilitating classroom inquiries to effectively enact" (p. 447). In order to understand teachers' prior beliefs and practices, this study aims to identify the participant teachers with regard to their inquiry teaching before a halfyear in-service program held in Helsinki, Finland. In addition, this study investigates the teacher's professional development through reflections during the program by the progress model of collaborative reflection.

\section{Literature ReVIew}

\section{Inquiry Teaching and Its Implementation}

Research interests in science education have gradually shifted from the nature of inquiry learning (Driver, 1983) to the feasible implementation of inquiry teaching. Inquiry has been regarded as an approach to bridge the gap between a scientist's way of doing science and a student's learning of science in school. Many science educators have defined inquiry learning by combining a series of student-centered activities. For example, Linn, Clark \& Slotta (2003) stated:

We define inquiry as a student's learning process and suggest inquiry as engaging students in the intentional process of diagnosing problems, critiquing experiments, distinguishing alternatives, planning investigations, revising views, researching conjectures, searching for information, constructing models, debating with peers, communicating to diverse audiences, and forming coherent arguments. (p. 518)

In line with this, Bell, Smetana \& Binns (2005) presented simplified levels of inquiry teaching as open, guided, structured, and confirmatory, considering how much a teacher directs each component of questioning, designing a method, and deriving conclusions. In a later article review, Bell, Urhahne, Schanze \& Ploetzner (2010) suggested a synthesis of inquiry activities identifying the main nine inquiry activities (orienting and asking questions, hypothesis generation, planning, investigation, analysis and interpretation, model, conclusion and evaluation, communication, and prediction).

The literature about implementation of inquiry teaching in secondary science discloses contextual challenges and their resolutions. Through an apprenticeship program in which scientist mentors guided secondary students, a dilemma emerged between the instructor's positive belief in inquiry teaching and the student's insignificant growth in scientific inquiry (Bell, Blair, Crawford \& Lederman, 2003). As they claimed, the "just-doing" of inquiry activities by students did not always guarantee inquiry teaching as 
intended. The challenge originates from the teacher's scant experience of student-centered learning through inquiry and suggests that it is not so easy for teachers who have been taught by teacher-centered instruction to employ a different manner of instruction when requested to change their paradigm (Kask et al., 2008). In this light, Gengarelly \& Abrams (2009) reported that teacher-scientist partnerships were an effective mean to ensure teachers' professional development.

\section{Progress Model of Collaborative Reflection}

As a framework for examining inquiry teaching, this study derives a progress model of collaborative reflection, based on two distinct research perspectives: individual and collaborative. From the individual perspective, many studies have focused on the relationship between belief and practice and have presumed two interactions: belief to practice (BP) and vice versa (PB). From the collaborative perspective, enacting collaborative reflections has been regarded as an effective strategy for promoting inquiry teaching because teachers learn from others who have implemented a new instruction more effectively (reinforcement, RE) and because trial lessons by other teachers might not coincide with their personal experience and stimulate professional development (stimulation, ST). Such collaborative reflections are intended to simultaneously broaden teachers' beliefs and their practices of inquiry teaching. The derived progress model recognized that the directional and dynamic reflections occurred in an interwoven and simultaneous progress and incorporated the four interactions of belief to practice, practice to believe, reinforcement, and stimulation as indicated below.

Belief To Practice. As shown in the quantitative study about the impact of teachers' belief on their professional practice using regression coefficient (Shireen \& Czerniak, 2003), one mainstream component of studies on teacher's professional development has presumed the directional influence from belief to practice. A later supportive, in-depth examination stated "teachers' beliefs, conceptions, attitudes, orientations, (personal) practical theories, and implicit or subjective theories about teaching were grounded in the understanding that these concepts drive teachers' practices" (Gay, 2010, p. 204). By means of teacher profiles, teacher's beliefs were shown to develop instructional practices in a secondary science classroom. Such a profile which enacts reflections among student teachers could be an effective tool to track their progress and to establish their lesson plans for future practices (Mansvelder-Longayroux et al., 2007). Furthermore, these qualitative studies could serve as examples of how a teacher program designer investigates teachers' beliefs beforehand, visualizes them in a type of self-regulated 
guideline for classroom experiences, and consequently formulates the practice.

Practice to Belief. As a priority could be taken as putting practice first and subsequently leading to a belief change, the next step in promoting teacher's professional development, related to a specific instruction, would be to guide them to implement practice and to reflect on their new experiences. For example, Tillema (2000) stated that practice or trial lessons, followed by reflection, promoted teacher's belief change relatively more than the opposite situation in which teachers plan their practices on the grounds of their beliefs. That was because these practices expanded teacher's prior experiences and reconstructed their own theoretical knowledge of instruction. Husu, Toom \& Patrikainen (2008) also noted the priority of practice. In their study, they employed the stimulated recall method in which a teacher's critical incident was chosen as material of an interview, in which questions were asked such as: "What happened in this incident?," "What comment can you make on this incident?," and "What is important and meaningful?" This strategy of guided reflection, based on the teacher practices, was reported to develop teacher's beliefs as intended in identifying social and cultural constraints or supports and in predicting their work in the future. In the same light, a design experiment method was applied to influence teacher's beliefs (Cobb, Zhao \& Dean, 2010). They addressed the three challenges that involve situating teacher's practice in his/her workplace or school, developing an interpretive framework, and connecting teacher's professional development in classrooms. These studies have suggested that situated instructional practices should be sustained over the long term to change teachers' beliefs by focusing on documenting and also adjusting to students' actual learning.

Stimulation. Studies that examine the social characteristics of professional development have recognized collaborative reflection as an effective component of pre-/in-service teacher programs. For example, Yoon \& Kim (2010) introduced dilemma cases as a strategy to provoke student teacher's collaborative reflection. They suggested that by sharing such situations, collaborative discussions could facilitate reflecting and learning from previous experiences. In other words, a teacher could stimulate his/her cognitive knowledge by reflecting the experimental situations of colleagues that might seemingly not be feasible for himself/herself. Husu et al. (2008) also developed their model for a situated recall method with particular regard to stimulating student teacher's reflective discussion. By introducing challenging experiments from colleagues in classrooms, a teacher program could raise the level of a teacher's stimulation beyond limits set by the concerns or partial objections from teachers' habitual practice. As a 
consequence, teachers could "question their practices, identify social and cultural constraints or facilitators, and also vision their work into the future." (p. 49). In this light, Fazio (2009) reported that a stimulation, in which a teacher evaluates others' practices, could develop contextual particulars in a local school to allow a focus on a more systematic awareness of the teacher's own practice.

Reinforcement. Apart from presenting dilemma cases through stimulations, a teacher program, which delivers a new method of instruction that has not been implemented widely among participant teachers, can introduce examples in the hope of reinforcing the particular practice. According to Uhrich (2009), the reinforcement in collaborative reflection is explained as taking place when a teacher cognitively consents to feasible and reliable situations presented by experts, allowing the teacher's beliefs and practices to evolve as the teacher intends. In Harford \& MacRuairc's (2008) study, the role of experts was replaced by peer videotaping in the classroom in order to promote participating teacher's reflective practices. They stated that the exposure to, and implementation of, diverse instructional methods reinforce teachers with indirect viable experiences about their practice. The tool helped teachers to build a community of practice wherein they subsequently demonstrated tangible evidence of development in the teaching context.

Structure of the Progress Model. In terms of the four components (BP, $\mathrm{PB}, \mathrm{ST}$, and RE) aforementioned, Figure 1 presents the progress model of collaborative reflection that has been partially considered in many professional development programs. Each cyclic arrangement depicts a participant teacher with his/her individual reflections: belief to practice and practice to belief, while the two dotted or arrowed straight lines show the two collaborative reflections with other participant teachers: stimulation and reinforcement. The model also symbolizes continuous and weblike collaborative reflections connected through the stimulation and reinforcement that are symbolized with the three cyclic arrangements; interactions from cyclic arrangements associated with other participants are omitted.

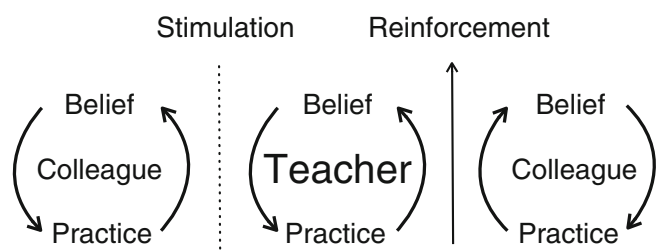

Figure 1. The progress model of collaborative reflection for an examination framework of in-service programs 


\section{Research Questions}

Many studies that examined science teachers during professional development programs have not considered the interwoven reflections captured in the literature review in this study. Most research findings have been based on a partial perspective of teacher reflections: individual or collaborative. The inquiry teaching, which requires a relevant and dynamic view of many classroom activities (Oliveira, 2010), has been shown in recent in-service programs, to give inconsistent progress of participant teachers (Taylor, Jones, Broadwell \& Oppewal, 2008). According to Cobb et al. (2010), teacher profiles and the evaluation framework should be addressed while conducting an innovative experimental program to support science teachers. Therefore, there emerges a need to examine how teachers learn to enact inquiry teaching through the progress model of collaborative reflection: $\mathrm{BP}, \mathrm{PB}, \mathrm{ST}$, and RE.

This qualitative research aims to monitor a half-year in-service program, the Professional Development Program for Inquiry Teaching, held in Helsinki, Finland and resolve the following research questions:

- Research question 1: What are the teacher profiles of inquiry teaching prior to the in-service program?

- Research question 2: As examined through the progress model of collaborative reflection, how do the participant teachers develop their belief and practice about inquiry teaching during the program?

\section{Methodology}

\section{The Professional Development Program for Inquiry Teaching}

As shown in Table A1, Appendix 1, the professional development program intended to provide science teachers in Finland with: (1) experience in planning, implementing, and reflecting modules of their trial lessons; (2) workplace collaborations which involve at least two teachers from a school; (3) theoretical workshops for collaboratively planning trials lessons using inquiry teaching modules; and (4) follow-up seminars for reflecting the results of their trial lessons and student's feedback. The theories and issues related to inquiry teaching, discussed in the program, include the levels of inquiry [open, guided, structured, and confirmatory inquiry (Bell et al., 2005)]; use of ICT as simulation and communication tools; various sources of information (text and figures from the Web, oral interviews, and story- 
telling); degree of reflection and interpretation of reflective strategies of teaching [HRASE strategy (Penick, Crow \& Bonnstetter, 1996)]; monitoring, evaluation, and metacognitive strategies $[K-W-L$ technique (Ogle, 1986)]; student learning motivation with regard to inquiry [Self-Determination Theory (Deci \& Ryan, 2000)]; and two models of inquiry teaching [5-E model (Carin, Bass \& Contant, 2004) and the POE model (White \& Gunstone, 1992)].

\section{Participants}

After an online advertisement via the Finnish Teachers' Union, seven registered members voluntarily responded and participated in the professional development program. Out of the seven, four teachers consented to interviews and videotaping in their schools; they are identified as Reena, Mali, Kai, and Lotti. Each teacher attended three 2-day meetings. It is notable that these four participants traveled from distant home cities to the program venue, the longest for $5 \mathrm{~h}$ by car, indicating sincerity and motivation to participate in the in-service program. Profiles of the four participant teachers were examined related to their belief and practice of inquiry teaching to provide answers to the first research question.

\section{Data Collection}

Three types of audio-video data were collected. Before the program, the first author visited the schools of each participant teacher to conduct semistructured interviews and to videotape their science lessons. During the program, $6 \mathrm{~h}$ of presentation and collaborative reflection of the teachers' trial lessons for inquiry teaching was videotaped. Finally, stimulated recall interviews were undertaken to triangulate with the author's interpretation of their beliefs and practices.

Semi-structured Interview. The semi-structured interview protocol asked the four main components of inquiry teaching, integrating the definitions by Bell et al. (2005) and Linn et al. (2003). Emphasis was placed on determining whether a teacher encourages students to construct questions, design investigations, derive models, and communicate with peers (see Appendix 2, Table A2 for further details). The other homogeneous components were placed in sub-questions, which identified whether the interviewees had illdefined their normal or occasional instruction as inquiry teaching. The whole protocol was face-validated by the five authors to ensure that each component and sub-questions sufficiently embodied inquiry teaching, and the English and Finnish language formats had been properly translated. 
During the interviews, the interviewees received the full protocol written both in English and Finnish. Each interview with the four participant teachers was planned to last for $50 \mathrm{~min}$.

Video Summarization Plus Field Notes. This method was employed to identify teacher's consistent characteristics found by the semi-structured interviews so as to reinforce triangulation of the data collection (Appendix 3 gives more details). According to Money and Agius (2008), video summarization enables researchers to develop condensed versions of full-length video interviews for identifying the most relevant and applicable contents for their analysis. Four types of audiovisual cues were used to depict succinct representations: The key frame cues that detect visual changes and capture their key frames, the video segment cues that convert a full-length video into a shortened movie, the graphical cues that add additional information on a two-dimensional block map of a video, and the textual cues that summarize a video by textual descriptors.

Stimulated Recall Interview. In this second interview, the participant teachers were asked to review the interview transcript and the video summarization of their lesson videos and to compare them with the authors' interpretation. The teachers were asked to reflect upon and to explain "why they did what they did, in their own terms" (Bishop, 2005, p. 116) in each school. After reviewing the materials as stimuli, each teacher was asked to corroborate whether the quotations and interpretations were reliable and representative of their beliefs and practices regarding inquiry teaching. Along with the reflection, the interviewer examined whether the program had produced any explicit change in teachers' beliefs and practices about inquiry teaching. Each stimulated recall interview with the four participant teachers was planned to last for $1 \mathrm{~h}$.

\section{Findings}

\section{Teacher Profiles of Inquiry Teaching Before the In-Service Program}

The beliefs and practices of inquiry teaching perceived among the four participant teachers are summarized in Table 1 . The abbreviations $\mathrm{R}, \mathrm{K}$, $\mathrm{L}$, and $\mathrm{M}$ indicate each respondent, while the numbers $1-4$ indicate each inquiry component ((1) to question the nature, (2) to design investigations, (3) to derive models, and (4) to communicate with peers). Both compatible and contradictory beliefs and practices for each component of inquiry teaching were determined for each teacher. 
Reena's Profile. She believed that she implemented inquiry teaching to some extent. Although her way of encouraging students to construct questions was confirmatory and ad hoc, she thought that the questions that her students asked during practical work maintained their interest in science. Inquiry activities were arranged when she finished explaining every concept and still had enough time remaining in the lesson. In her opinion, her students enjoyed their practical work, diversifying their investigations and actively talking aloud to their peers about esthetic findings. However, her students seldom documented their laboratory work as systematically as she intended; it was said to be her challenge for inquiry teaching. Such weakness hindered the students from combining their experimental conclusions into a theory or concept. For this reason, she adhered to instructions from the textbooks.

Reena: When they [Reena's students] are doing so [experiments], they always ask me afterwards, 'Can I mix what I want?' They like it very much. It is inquiry in their sense (R1); ... I mean in this book [textbook \#1], there is no openness in my mind. It was difficult. But, also even in here [textbook \#2], everything is like a cookbook, saying dothis and do-this. I have another book [textbook \#3], the new book. I mean how they present the work. This is very nicely done (R2); ... They really enjoy trying everything. It is the same as in Heureka [Finnish National Science Centre]. You must push and pull everything. ... But, they are not very systematic (R3); ... They enjoy showing that they are capable of doing something. But, the results are not science. They are not able to find anything that Einstein would (R4).

Kai's Profile. According to the interview, her way of teaching science turned out to be unique with emphasis on social interaction between student peers. She compared doing science to producing large amounts of data and discussing results as if students were at an academic conference. Her perception of learning science was a social activity. In the authors' interpretation, she was fully implementing guided inquiry in which questions and investigations were given, and conclusions remained to be discussed among students. To provoke inquiry during a laboratory work, she instructed her students to perform "multiple-group circulation" and to take up the roles of leader, assistants, and a scribe.

For example, in her chemistry lesson, there were four different types of arrangements with different acids that students had to examine. In the first round, they formed a group and each took up a role. After finishing their first experiments in these roles, the students switched roles in order to form a reformulated new group for the second round of experiments. Thus, in the second round, each student may have a different role. 
TABLE 1

Teacher profiles in terms of beliefs and practices of inquiry teaching

\begin{tabular}{|c|c|c|c|c|}
\hline Teacher & $\begin{array}{l}\text { Question the } \\
\text { nature }\end{array}$ & $\begin{array}{l}\text { Design } \\
\text { investigations }\end{array}$ & Derive models & $\begin{array}{l}\text { Communicate } \\
\text { with peers }\end{array}$ \\
\hline Reena & $\begin{array}{l}\text { R1. Students ask } \\
\text { many questions } \\
\text { for instant } \\
\text { confirmations. } \\
\text { This interview } \\
\text { could not reveal } \\
\text { much of student's } \\
\text { questioning of the } \\
\text { nature. }\end{array}$ & $\begin{array}{l}\text { R2. It depends } \\
\text { mainly on which } \\
\text { textbook the } \\
\text { students use. }\end{array}$ & $\begin{array}{l}\text { R3. Lower } \\
\text { secondary } \\
\text { students are more } \\
\text { eager to } \\
\text { manipulate } \\
\text { scientific objects. } \\
\text { However, they } \\
\text { cannot reach } \\
\text { sophisticated } \\
\text { conclusions. }\end{array}$ & $\begin{array}{l}\text { R4. Students enjoy } \\
\text { casual discussion } \\
\text { which is, } \\
\text { however, less } \\
\text { scientific. }\end{array}$ \\
\hline Kai & $\begin{array}{l}\text { K1. She sees the } \\
\text { need to motivate } \\
\text { student's } \\
\text { questioning of } \\
\text { nature. }\end{array}$ & $\begin{array}{l}\text { K2. She sets roles } \\
\text { (a leader, } \\
\text { assistants, and a } \\
\text { scribe) for groups } \\
\text { of students. Each } \\
\text { leader is } \\
\text { encouraged to } \\
\text { decide on a } \\
\text { design. }\end{array}$ & $\begin{array}{l}\text { K3. She encourages } \\
\text { students to } \\
\text { formulate their } \\
\text { results and } \\
\text { discuss them with } \\
\text { other, as a real } \\
\text { scientist would } \\
\text { do. }\end{array}$ & $\begin{array}{l}\text { K4. She encourages } \\
\text { students to } \\
\text { circulate in } \\
\text { multiple groups } \\
\text { and discuss with } \\
\text { each new } \\
\text { member. }\end{array}$ \\
\hline Lotti & $\begin{array}{l}\text { L1. She understands } \\
\text { that questioning is } \\
\text { mainly about the } \\
\text { students } \\
\text { constructing } \\
\text { confirmation and } \\
\text { asking her } \\
\text { answers. }\end{array}$ & $\begin{array}{l}\text { L2. Her example of } \\
\text { designing an } \\
\text { investigation in } \\
\text { IT class is } \\
\text { irrelevant. }\end{array}$ & $\begin{array}{l}\text { L3. She understood } \\
\text { that a model is a } \\
\text { type of } \\
\text { experimental } \\
\text { equipment. }\end{array}$ & $\begin{array}{l}\text { L4. Not much } \\
\text { discussion takes } \\
\text { place in her } \\
\text { science lesson. }\end{array}$ \\
\hline Mali & $\begin{array}{l}\text { M1. She tries to } \\
\text { give students } \\
\text { initiating } \\
\text { questions. The } \\
\text { examples of her } \\
\text { questioning are } \\
\text { focused on } \\
\text { dialogues } \\
\text { between teacher } \\
\text { and student. }\end{array}$ & $\begin{array}{l}\text { M2. It could be } \\
\text { open and } \\
\text { structured } \\
\text { depending on the } \\
\text { experimental } \\
\text { topic. }\end{array}$ & $\begin{array}{l}\text { M3. She makes it } \\
\text { clear to the } \\
\text { students what has } \\
\text { been learned in a } \\
\text { science lesson. }\end{array}$ & $\begin{array}{l}\text { M4. She encourages } \\
\text { students to } \\
\text { discuss in groups. } \\
\text { In addition, she } \\
\text { also gives } \\
\text { authentic } \\
\text { answers, when } \\
\text { the discussion is } \\
\text { misled. }\end{array}$ \\
\hline
\end{tabular}

Because the second arrangement had different acids, each member had to explain what she/he had found in the previous group. Since many of her lessons were organized to have multiple-group circulation, the students did not bother each other, and they could concentrate on conducting 
experiments and discussing findings with their peers. In addition, she believed that, by doing the multiple-group circulation and the roleplaying, students could teach each other in their own language which was expected to be more effective than the teacher's explanation. This strategy could also save physical space for doing experiments, since each student focuses only on their tools to use.

However, she admitted to having a challenge in implementing open inquiry and wished to learn how to initiate students' questions. This concern first originated from the student's poor understanding of the importance of learning objectives. In general, she explained the reason and significance of the day's experiment related to the society. Her challenge was to guide her students to appreciate why their practical work was important.

Kai: I hope that they [my students] could formulate questions more often, but as I said I usually used the questions from the texts.... I think it would be good if they could make the questions by themselves. But, I do not know how to get them to do so. So, it would be nice to have some tips or help for doing this [in the in-service teacher program] $(\mathrm{K} 1)$; ... Usually, the practical work in the classroom is like [the experiment] we did today. I put them into groups and inside the group there will be four different roles [where] one is the boss (K2); ... [She spoke to her students that] 'you are a professional doing the experiment.' and 'you have to tell the others what your results are and what was happening in your groups and everything'. ... [In her classes] it is like a little conference (K3); ... everybody doing their own bit and then, after each experiment they change groups forming the new groups from different sets of students. They form a group and tell their new group members what they had been doing (K4).

Lotti's Profile. Her incompatible responses implied her confusion in understanding inquiry teaching, although she claimed that she encouraged her students to do the first three components associated with inquiry teaching. Her examples in the interview or the video analysis were hardly consistent with the inquiry teaching. She said that, in her lessons, students were engaged in the activities of questioning, investigating, and modeling. However, her examples embodied contradictory situations: Students asked the teacher questions which were not about questioning the nature; they searched the Internet, not designing investigations for themselves; they made models of plastic equipment, not modeling their findings into a theory. In her superficial understanding, the meaning of "inquiry teaching" was so unfamiliar that she might not have considered it for her science lessons. For the fourth component of inquiry teaching, communicating with peers, she did not believe it was needed because of the reserved nature of the 
Finnish people. Thus, she rarely included peer communication activities.

Lotti: Well, they [my students] do [ask questions] a lot, when they do not know something and when they do not understand something. I always say that they should do so (L1); our planned schedule is very strict. So, we do not have much time for that; ... Well, one was on this week when we went to the IT class, [and] then they started their meta searching of the Internet. And, they made a little essay about that (L2); ... Chemistry and molecules. We also have this physics of air tubes (L3); ... They do not argue so much. They believe what I say. They do not have many opinions of their own. They do the work and then they have the results and they do discuss it a little bit with each other, but not so much (L4).

Mali's Profile. She was in charge of seventh graders' physics and chemistry. As her students were younger and had just started taking the specialized science subjects first introduced after primary school, she was focusing much on the fundamental and academic differences between physics and chemistry. Since the introduction to the advanced science subjects was her belief of teaching the students, she focused on following the curriculum, textbook, and instructions in each experiment. For the interview question on constructing questions about the nature, she explained that her students asked many direct questions to her. If the student question was in line with main topics of the day, she shares it with other students. On the other hand, she answered the question immediately, if the question was not relevant. The same rule was applied when students planned their own investigation. She mentioned the example of "moonlight." When a student asked, "Does the moon emit light as well?" she had to answer this question directly. That was because this phenomenon was too advanced for students to examine by any experiment. Mali was aware of the importance of students constructing questions. In practice, however, the seventh graders' weak metaknowledge of learning did not permit them to develop their questions to the open inquiry. In another sense, such diversity in the student's cognitive level encouraged her students to collaborate with each other by speaking "their language."

Mali: I normally try to turn the questions back to the students. 'OK, what do you think about it.' ... if it seems that the questions are a little bit too difficult to answer and I cannot expect them to know the answer, then I answer it (M1); ... I try to do some kind of open experiments so I only give them a starting discussion statement, for example: 'Now we have discussed optics today'. ... Sometimes, I just give them very straight kind of rules, which the groups have to follow exactly (M2); ... I tell them they have to write reports for experiments. And, they are doing the conclusions in writing down those conclusions. But, sometimes, I give them the conclusions. (M3); ... When the students are doing their 
experiments, they always can discuss with each other. So, I never ask them to be quiet. ... And they don't often argue with me. ... If it is [an] obvious thing, then I only show them, [saying] 'OK, this is it' (M4).

\section{Consistency from Lesson Videos and Field Notes}

The analysis of lesson videos and field notes taken before the inservice program supported that the teacher profiles were consistent and representative with regard to the inquiry teaching (see Appendix 3, Table A3). In Reena's science lesson, she first explained the concepts in chemistry for 11/30th of the lesson, then spent seven blocks for student's hand-on activities with molecular models, provided student-centered time for documenting the findings in a textbook for another seven blocks, and gave them a closing lecture for the remaining five blocks. What to note in the science lesson was that she spent an even amount of time for the students to self-report their findings in their textbook. Her practice, as shown in the classroom video, was interpreted as being significantly consistent to her profile because she claimed in the interview that instructions in a textbook matter much for designing student's investigations.

In Kai's science lesson, she demonstrated to the students how to play roles for their group work. After delivering an introduction to the subject for nine blocks of time, she drew a table for the students to decide their roles in each group: a director, two assistants, and a scribe. The rest of her lesson, 19 out of 30 blocks, involved her students continuing the group activities with her occasional guidance.

In Lotti's science lesson, none of the four components of inquiry teaching was significantly monitored. This insignificance is in line with her profile when she could not respond to any relevant component of inquiry teaching. In Mali's lesson video, consistently monitored was that she taught her students both by allowing them autonomy and demonstrating how to correctly conduct the experiment.

\section{Trial Lessons and Collaborative Reflections Examined by the Progress Model}

During teacher presentations of their inquiry trial lessons to the inservice course participants, the four teachers reflected feelings of unexpectedness, describing each science lesson in which inquiry teaching was more effective than their expectation. Their experience 
was linked to their teacher profiles measured by the semi-structured interview and the lesson videos. Along with these individual reflections, collaborative reflections were undertaken after each presentation. Employing the progress model, the presentations or brief descriptions of each trial lesson below capture the interwoven reflections. In this section, the teacher presentations are presented in the third person constructed by the first authors as observer. The author's interpretation of the interwoven reflections are added between brackets [ and ], while the presentation videos are summarized in text cues as they were spoken.

Lotti's Presentation of Her Trial Lesson. She presented her lesson involving a chemistry experiment on how to make an electric cell. She first demonstrated a chemical electric cell built in a beaker. The following student's task was to make electric sparks mimicking the teacher's electric cell by using different materials: coins, aluminum foil, wires, salt, paper towel, water, plus any beakers they needed.

Lotti: To encourage student group discussions, I organized them to set roles for each group member: a leader, assistants, and a scribe, as Kai introduced it during the previous program [This is linked to K4 and interpreted as Lotti's RE].

In preparing the inquiry lesson, Lotti was not sure how the lesson would advance; all the students were confused at the beginning. Many students dipped the coins and foil into beakers with salty water together, which was a faulty setup. So, she decided to give them another hint "Do not dip any metals in the beakers." Still, the students created types of malfunctioning structures and wondered, "Why is this setup not producing any spark?" As her class had a special-needs student who has difficulty in communicating with others and got emotionally unstable [due to a type of Asperger syndrome], she was anxious about the group in which the student was working.

Lotti: After some time, the group with the special-needs student could construct the most probable setup. Little by little, the members got to understand the key structure of an electric cell. The special-needs student looked very glad with what his group had accomplished. How I could integrate him into the group had been my main concern before the inquiry lesson, but it turned out that my inquiry teaching could involve him in studentcentered activities as well (Lotti's PB).

Collaborative reflections followed after Lotti's presentation, Reena first, asked whether the students had asked Lotti many questions. [It was known in the pre-interview that Reena's students often asked for 
confirmation (Reena's ST from R1).] Lotti replied "No," since the students were confused by what they had constructed and they could not formulate any further questions, except asking each other: "Why is this not working?" Mali added that students are often puzzled by what they observe, and they normally cannot recognize or formulate such wonder into questions (Mali's RE from M1). Next, Reena asked her second question "Did the students use any textbook?" Lotti answered that the students had the textbook, but she did not ask them to read it. [Reena believes students' open investigations are dependent on their textbook, which is at odds with Lotti's trial lesson (Reena's ST from R2).] Lotti said that she had used textbooks in a prior class for learning the concept of ionization, but not for designing investigations. In summary, Lotti's trial lesson from her planning to the collaborative reflections can be presented in terms of the teacher profiles (K4, R1, and R2) and the progress model (RE, PB, and ST) as follows:

K4 $\rightarrow$ Lotti's RE $\rightarrow$ Lotti's trial lesson $\rightarrow$ Lotti's PB $\rightarrow$ Reena's ST from $\mathrm{R} 1 \rightarrow$ Mali's RE from M1 $\rightarrow$ Reena's ST from R2

Reena's Presentation of Her Trial Lesson. Based on her belief of textbook for a tool of student inquiry (R2), Reena introduced her trial lesson with a learning strategy of reading textbooks (BP). Even though the eighth graders were about to have a test in days, they did not read the textbook enough. She mentioned that careful textbooks reading would help students to learn a lot. In one physics class, Reena gave students a $2 \times 2$ inquiry table where each cell was labeled with "I do not understand this part," "This part is familiar to me," "This part is where I want to know more," and "This part needs to be learned by heart." She asked students to read and fill each cell. She stated that:

Reena: Although this trial lesson was not familiar to students, they concentrated in reading the textbook. To my surprise, the low-achievers were involved in this trial as much as the higher-achievers (PB).

Collaborative reflections followed after Reena's presentation. Lotti mentioned that she would like to try Reena's trial lesson (RE), due to its simple design. Reena again addressed the skill of reading needed for learning. Comparing Reena's trial lesson to her own, Mali interpreted that the $2 \times 2$ inquiry table strategy must have led students to reflect their own learning progress and previous knowledge (RE). However, Reena admitted that she needed more ideas of how to continue such a trial lesson. For her, it was not likely that students could concentrate on such 
inquiry of constructing questions in every lesson. In summary, Reena's trial lesson from her planning to the collaborative reflections can be presented in terms of the teacher profiles (R2) and the progress model (BP, $\mathrm{PB}$, and $\mathrm{RE}$ ) as follows:

R2 $\rightarrow$ Reena's BP $\rightarrow$ Reena's trial lesson $\rightarrow$ Reena's PB $\rightarrow$ Lotti's RE $\rightarrow$ Mali's RE

Kai's Presentation of Her Trial Lesson. In this lesson, Kai organized student's presentations on energy production. Although she is used to formulating questions in a very structured way, in her trial lesson, she chose a new teaching approach. The tasks given to students were "Imagine that you are one of the following experts who are presenting the topic of electricity for your house. What kind of questions could you answer, if you were a fire fighter, an insurance salesman, a worker in a nuclear power plant, or a Greenpeace representative?" The students were allowed 20 min for the group work. Every student had to write questions in a computer class after the lesson. At the beginning of the next lesson, Kai suggested possible viewpoints for open discussion on a board: occupation, history, environment, production, and economy. Then, students were asked to classify their questions through group discussion.

Collaborative reflections followed after Kai's presentation. She was asked to describe details of the topics taught in the previous class. So, Kai put the students' notes on a screen. She continued describing the trial lesson; students classified the questions under the given roles. A student group had to select one viewpoint and prepare it for a presentation. Reena asked how many questions the students needed to answer [Reena was fond of giving instructions for students' activities; she might doubt Kai's trial lesson of open instruction (ST from R2)]. Kai replied that students were free to choose their own questions. Kai expressed her surprise at the quality questions that the students came up with (PB).

Kai: This session concentrated on students' own questions. My first impression was that the boys came up with more questions, while the girls just wrote a list of questions. ... The topic of the questions is related to living places, as my school is located close to a nuclear power plant. In these first two of six lessons focusing on energy production, I was proud about the quality of questions the students asked (PB).

In line with this, Mali commented that the boys' questions were more probing than the girls' (RE). Lotti mentioned that, when she had heard about it from Kai in their school, she tried a similar trial lesson (RE) using a slightly 
different approach with a more liberal structure: Students were asked to invent the classification viewpoints as well. In summary, Kai's trial lesson from her planning to collaborative reflections can be presented in terms of the teacher profiles (R2) and the progress model (PB, ST, and RE) as follows:

Kai's trial lesson $\rightarrow$ Kai's PB $\rightarrow$ Reena's ST from R2 $\rightarrow$ Mali's RE $\rightarrow$ Lotti's RE

Mali's Presentation of Her Trial Lesson. She presented her trial lesson in which she used the $K-W-L$ method for facilitating student's questions [that was similar to Reena's for textbook activity with the $2 \times 2$ inquiry table (RE from R2)]. She explained to her students that $K$ is what they know, $W$ is what they would like to know, and $L$ is what they have learned. Her students were asked to write them on sheets of paper provided. She taught the basics of optical lenses to the 12 students. Reflecting on their prior knowledge, students wrote some terms concerning the basic concepts of optics. The students asked many questions. Mali classified these questions as why-questions. During the lesson, the focus was set on how-questions at the beginning and later students asked why-questions. In short, Mali's trial lesson of inquiry teaching focused on facilitating student questioning.

Mali: Students discussed questions, collected the relevant equipment, and conducted experiments. I think this process is student's learning, because of the high quality of the student's question. ... After the students wrote the questions, every question was discussed, and some of them were demonstrated and tested. ... I believed that, because this trial lesson was done before the student's exam, [the] students' answers in the exam were rather better (PB).

Collaborative reflection followed after Mali's presentation. Reena first asked about what was taught before the lesson. Afterward, Lotti mentioned that this method seemed very effective in facilitating student questioning (RE). In summary, Mali's trial lesson from her planning to the collaborative reflections can be presented in terms of the teacher profiles (R2) and the progress model (PB and RE) as follows:

$\mathrm{R} 2 \rightarrow$ Mali's RE $\rightarrow$ Mali's trial lesson $\rightarrow$ Mali's PB $\rightarrow$ Lotti's RE

\section{Consistency from Stimulated Recall Interview}

In the second interview, the teacher profiles in Table 1 and the video summarization in Figure A1, plus its interpretation in Table A3 
(Appendix 3) were presented to each teacher. They examined whether the data were reliable and whether their practices were representative with respect to their normal teaching. Every respondent partly corrected the materials. For example, Lotti corrected the demonstration in her trial lesson. When she built a chemical electric cell, she used one beaker, but not two. Reena pointed out the quotation "I thought that the textbook mainly decides 'inquiry teaching' and students need straight instruction of experiments." She felt it was more correct if she specified it in a more focused manner as "designing investigations," not generalizing her teaching to extension of inquiry teaching. Other than these modifications, the four respondents approved the selection of their quotations and the authors' interpretation.

In addition, they claimed their intention to teach the topics with the inquiries in following years, based on their positive experiences of the trial lesson. In line with the interwoven collaborative reflections examined by the progress model, they recalled their positive experience during the trial lessons: Lotti found that her special-needs student was more involved in the student-centered activity during her student-centered trial lesson; Reena found that the low achievers were as much involved in her trial lesson as the higher achievers were; Kai was satisfied with the quality of student's scientific questions to the given topic; Mali was surprised that those students who worked on the $K-W-L$ activity (Ogle, 1986) had better scores in the subsequent examination. However, even with all these positive experiences, none of them mentioned that their prior beliefs and practices changed during the in-service program. That is, their positive experience and sustainable intention of using inquiry teachings were not explicitly recognized as a change of their beliefs.

\section{Conclusion}

This section highlights the most relevant findings to answer the two research questions. First, the teacher profiles examined by the four components of inquiry teaching are discussed among the four participants. Subsequently, each profile incorporates terms from the progress model of collaborative reflection.

\section{Answer to Research Question 1: Multiplicity of Inquiry Teaching}

Since the most recent literature indicates that a teacher's profile is an effective tool for understanding teacher's progress in an in-service 
program, it was crucial to examine the participant teachers' beliefs and practices about inquiry teaching (Tobin, Tippins \& Gallard, 1994). When interviewed by the conventional criteria-whether teachers encourage their students to construct questions, design investigations, derive models, and communicate with their peersderived from the literature (Bell et al., 2005; Linn et al., 2003), each participant teacher was found to have strengths and weaknesses related to inquiry teaching (Table 1).

No straightforward evaluation of the teachers' beliefs and practices complying with the authentic definition or the levels of inquiry teaching was possible regarding the multiplicity of ways participants organized inquiry teaching. For example, Reena encouraged students to frequently discuss their experiments (R4) for sustaining student's interest in a given topic, while she believed following instructions in a textbook is a key component for guiding student's experiment design (R2). Kai was characterized in her beliefs and practices as encouraging student's discussion in peer groups in science lessons (K4), whereas she admitted that she lacked knowledge of how to promote student construction of questions (K1). Mali tried to explain the diverse variety of her instructions as being dependent on the nature of the science topics dealt with in each class (M1, 2, 4). Still, she consistently appreciated the "correct" science, mentioning that there exist concepts that students should learn by her authentic demonstrations and explanations (M3).

\section{Answer to Research Question 2: Interwoven Progress Developed from Prior Belief and Practice}

The progress model of collaborative reflection monitored deeper understanding of the individual and collaborative reflections during the in-service teacher program, in terms of BP, PB, RE, and ST. That is, each participant teacher presented interwoven progress toward inquiry teaching, even though she/he could not explicitly recognize that there existed a degree of progress such as the positive experiences after the trial lessons and the intentions of replicating them.

For example, Figure 2 presents a part of the interwoven progress. Kai's peer discussion strategy (K4) guided Lotti to organize the student-centered experiment in her trial lesson (RE), which consequently resulted in her positive experience (PB). These trial lessons were interpreted as stimulating to Reena (ST), since Lotti and Kai's 


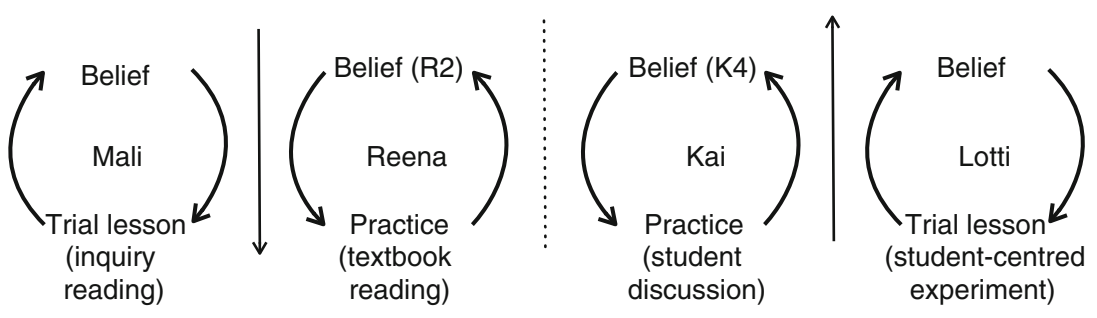

Prior belief and practice R2: For Reena, designing investigations depends mainly on which textbook students use. Prior belief and practice K4: Kai encourages students to circulate in multiple groups and discuss with each new member.

Figure 2. A part of the interwoven progress developed from teacher's prior beliefs and practices about inquiry teaching during the in-service program

success was conflicting with her dominant belief and practice related to authentic instructions given by textbooks (R2). On the other hand, Reena's belief about the authentic instruction in textbooks formulated her trial lesson to include a learning strategy for reading textbooks (BP). Subsequently, Mali (RE) adopted this textbook-centered lesson with the inquiry reading and produced another positive experience (PB). Lotti also agreed that Mali's trial lesson could be effective in facilitating student questions (RE).

\section{Implication and Further Research Questions}

\section{The Progress Model for Designing and Evaluating In-Service Programs}

In the teacher's collaborative reflection and the stimulated interview during the in-service program, McGee \& Lawrence's (2009) time constraint or commitment to sustainable change was not addressed as a challenge for practicing their student-centered inquiry teaching. Rather, the participant teachers found the trial lessons effective in their school contexts, through implementing their unique inquiry lesson plans: integrating a special-needs student or low-achievers, guiding students to read textbooks, and enhancing scores in a school exam. In their responses, the participants found personalized reasons to sustain inquiry teaching; they did not view sustainability as an external commitment. These findings are in line with Anderson \& Mitchener's (1994) statement that in-service education should aim to promote personalized development from their pre-existing beliefs and practices or teacher profiles in school contexts, with regard to their teaching habits, physical and cultural constraints, and affordances of the school and education. 
In this light, this small-sample qualitative research, which analyzed teacher's interwoven reflections for inquiry teaching, proposes an empirical approach to designing and evaluating teacher-training programs: (1) the programs need to facilitate both individual and collaborative reflections so as to enlarge teacher's prior beliefs of inquiry teaching and to ensure their sustainable practices; (2) the evaluation should not be conducted only on the teachers' explicit changes but also on the enrichment of their instruction repertoire, since the professional development emerges without teachers' explicit self-recognition. In practice, science teacher educators who aim to disseminate inquiry teaching are recommended to employ combined methods such as a semi-structured interview, summarization of classroom videos, and a stimulated recall interviews to reliably identify teacher's beliefs and practices before and during a teacher-training program and to consider the progress model of collaborative reflection in terms of BP, PB, ST, and $\mathrm{RE}$ for evaluation, without expecting rapid paradigm shifts in teaching science within a limited period.

\section{Further Research Questions}

How does the implicit development incorporate a richer repertoire of teaching practice? How does the implicit development in teacher's belief evolve into the core development? The teacher's interwoven progress discloses that the participants in an in-service program have developed their sustainable beliefs and practices toward inquiry teaching (Figure 2). Noticeable from the results is that the progress was examined to be implicit without teacher's self-recognition according to the stimulated recall interview. Vaino (2009) categorized types of teacher beliefs that in-service teacher programs could promote: the core development (stated and enacted), the peripheral development (stated but not enacted), and the emerging development (newly stated beliefs caused by the intervention). All the empirical findings and the theoretical discussion suggest a fourth component after Vaino's three types of belief development - the implicit development. That is, teachers' beliefs related to inquiry teaching might not be properly stated, although they were practically enacted with teacher's sustainable intention. Hashweh (1996) explained such implicit development in terms of the richer repertoire referred to as "the constructivist teachers used a greater number of singleand multiple-type teaching strategies, revealing richer repertoires of teaching strategies" (p. 61). Regarding the discussion, the progress model provides visible explanations of how in-service programs sustain teacher's intention of practicing their trial lessons so as to enact the core development and how the 
programs eventually develop cohort of teachers, schools, and curricular, as intended.

\section{REFERENCES}

Anderson, R. D. \& Mitchener, C. P. (1994). Research on science teacher education. In D. L. Gabel (Ed.), Handbook of research on science teaching and learning (pp. 3-44). New York: Macmillan.

Bell, R. L., Blair, L. M., Crawford, B. A. \& Lederman, N. G. (2003). Just do it? Impact of a science apprenticeship program on high school students' understandings of the nature of science and scientific inquiry. Journal of Research in Science Teaching, 40(5), 487-509.

Bell, R. L., Smetana, L. \& Binns, I. (2005). Simplifying inquiry instruction: Assessing the inquiry level of classroom activities. The Science Teacher, 72(7), 30-33.

Bell, T., Urhahne, D., Schanze, S. \& Ploetzner, R. (2010). Collaborative inquiry learning: Models, tools, and challenges. International Journal of Science Education, 32(3), 349.

Bianchini, J. A. \& Colburn, A. (2000). Teaching the nature of science through inquiry to prospective elementary teachers: A tale of two researchers. Journal of Research in Science Teaching, 37(2), 177-209.

Bishop, R. (2005). Freeing ourselves from neocolonial domination in research: A Kaupapa Mãori approach to creating knowledge. In N. K. Denzin \& Y. S. Lincoln (Eds.), The Sage handbook of qualitative research (pp. 109-138). Thousand Oaks, CA: Sage.

Bybee, R. W. (1997). Achieving scientific literacy: From purposes to practices. Portsmouth, NH: Heinemann.

Carin, A. A., Bass, J. E. \& Contant, T. L. (2004). Teaching science as inquiry (10th ed.). Upper Saddle River, NJ: Prentice Hall.

Cobb, P., Zhao, Q. \& Dean, C. (2010). Conducting design experiments to support teachers' learning. The Journal of the Learning Sciences, 18(2), 165-199.

Deci, E. L. \& Ryan, R. M. (2000). The "what" and "why" of goal pursuits: Human needs and the self-determination of behavior. Psychological Inquiry, 11(4), 227-268.

Driver, R. (1983). The pupil as scientist? Milton Keynes, UK: Open University Press.

Falk, J. K. \& Drayton, B. (2009). MSPnet: Design dimensions for nested learning communities. Creating and sustaining online professional learning communities (pp. 17-46). New York: Teachers College, Columbia University.

Fazio, X. (2009). Teacher development using group discussion and reflection. Reflective Practice, 10(4), 529-541.

Gay, G. (2010). Acting on beliefs in teacher education for cultural diversity. Journal of Teacher Education, 61(1-2), 143-152. doi:10.1177/0022487109347320.

Gengarelly, L. \& Abrams, E. (2009). Closing the gap: Inquiry in research and the secondary science classroom. Journal of Science Education and Technology, 18(1), 74-84.

Harford, J. \& MacRuairc, G. (2008). Engaging student teachers in meaningful reflective practice. Teaching and Teacher Education, 24(7), 1884-1892.

Hashweh, M. Z. (1996). Effects of science teachers' epistemological beliefs in teaching. Journal of Research in Science Teaching, 33(1), 47-63.

Hiebert, J., Gallimore, R. \& Stigler, J. (2002). A knowledge base for the teaching profession: What would it look like and how can we get one? Educational Researcher, 31(5), 3-15. 
Husu, J., Toom, A. \& Patrikainen, S. (2008). Guided reflection as a means to demonstrate and develop student teachers' reflective competencies. Reflective Practice: International and Multidisciplinary Perspectives, 9(1), 37.

Johnson, M. A. \& Lawson, A. (1998). What are the relative effects of reasoning ability and prior knowledge on biology achievement in expository and inquiry classes? Journal of Research in Science Teaching, 35(1), 89-103.

Kask, K., Rannikmäe, M., \& Mamlok-Naaman, R. (2008). A paradigm shift in science teaching - Teacher development for inquiry teaching. In J. Holbrook, M. Rannikmäe, P. Reiska, \& P. Isley (Eds.), The need for a paradigm shift in science education for Post-Soviet societies: Research and practice (Estonian example) (pp. 47-66). Berlin: Peter Lang.

Kuhn, T. S. (1996). The structure of scientific revolutions (3rd ed.). Chicago, IL: University of Chicago.

Lavonen, J., \& Laaksonen, S. (2009). Context of teaching and learning school science in Finland: Reflections on PISA 2006 results. Journal of Research in Science Teaching, 46 (8), 922-944.

Linn, M. C. (2009). Foreword. In J. K. Falk \& B. Drayton (Eds.), Creating and sustaining online professional learning communities. New York: Teachers College, Columbia University.

Linn, M. C., Clark, D. \& Slotta, J. D. (2003). WISE design for knowledge integration. Science Education, 87(4), 517-538.

Mansvelder-Longayroux, D. D., Beijaard, D. \& Verloop, N. (2007). The portfolio as a tool for stimulating reflection by student teachers. Teaching and Teacher Education, 23(1), 47-62.

McGee, A. \& Lawrence, A. (2009). Teacher educators inquiring into their own practice. Professional Development in Education, 35(1), 139-157.

Money, A. G. \& Agius, H. (2008). Video summarisation: A conceptual framework and survey of the state of the art. Journal of Visual Communication and Image Representation, 19(2), 121-143.

National Research Council (NRC). (1996). National Science Education Standards. Washington, DC: National Academy Press.

Nelson, T. H. (2009). Teachers' collaborative inquiry and professional growth: Should we be optimistic? Science Education, 93(3), 548-580.

OECD. (2007). PISA 2006 science competencies for tomorrow's world: Volume 1. Paris, France: Organisation for Economic Co-operation and Development (OECD).

Ogle, D. M. (1986). KWL: A teaching model that develops active reading of expository text. The Reading Teacher, 39(6), 564-570.

Oliveira, A. W. (2010). Improving teacher questioning in science inquiry discussions through professional development. Journal of Research in Science Teaching, 47(4), 422-453.

Penick, J. E., Crow, L. W. \& Bonnstetter, R. J. (1996). Questions are the answer: A logical questioning strategy for any topic. The Science Teacher, 63(1), 27-29.

Shireen, J. M. \& Czerniak, C. M. (2003). Study of science teachers' attitudes toward and beliefs about collaborative reflective practice. Journal of Science Teacher Education, 14(2), 75-96.

Sowder, J. T. (2007). The mathematical education and development of teachers. In F. K. Lester Jr. (Ed.), Second handbook of research on mathematics teaching and learning (2nd ed., pp. 157-224). Charlotte, NC: National Council of Teachers of Mathematics.

Taylor, A. R., Jones, M. G., Broadwell, B. \& Oppewal, T. (2008). Creativity, inquiry, or accountability? Scientists' and teachers' perceptions of science education. Science Education, 92(6), 1058-1075. doi:10.1002/sce.20272. 
Tillema, H. H. (2000). Belief change towards self-directed learning in student teachers: Immersion in practice or reflection on action. Teaching and Teacher Education, 16(5-6), 575-591.

Tobin, K., Tippins, D. J. \& Gallard, A. J. (1994). Research on instructional strategies for teaching science. In D. L. Gabel (Ed.), Handbook of research on science teaching and learning (pp. 45-93). New York: Macmillan.

Tytler, R., Osborne, J., Williams, G., Tytler, K. \& Cripps, C. J. (2008). Opening up pathways: Engagement in STEM across the primary-secondary school transition. Canberra, Australia: Australian Department of Education, Employment and Workplace Relations.

Uhrich, T. A. (2009). The hierarchy of reflective practice in physical education. Reflective Practice, 10(4), 501-512.

Vaino, K. (2009). Identifying chemistry teacher's beliefs. Science Education International, 20(1/2), 32-43.

Wellington, J. (1989). Skills and processes in science education: An introduction. In J. Wellington (Ed.), Skills and processes in science education (pp. 5-20). London: Routledge. White, R. T. \& Gunstone, R. F. (1992). Probing understanding. London: Routledge.

Yoon, H.-G. \& Kim, M. (2010). Collaborative reflection through dilemma cases of science practical work during practicum. International Journal of Science Education, 32(3), 283.

Minkee Kim

Graduate School of Education

Bilkent University

Ankara, 06800, Turkey

E-mail:physhero@gmail.com

Jari Lavonen and Kalle Juuti

The University of Helsinki

Helsinki, Finland

Jack Holbrook and Miia Rannikmäe

The University of Tartu

Tartu, Estonia 